\title{
Synthesis and Polymerization of Poly Acryl Imide and One of Their Derivatives Then Curing the Product with Alkyl Halide
}

\author{
Entesar O. Al-Temimi* \\ Sameaa J. Al-Bayati**
}

Date of acceptance $1 / 3 / 2010$

\begin{abstract}
The present work involved four steps:

First step include reaction of acrylamide, N-Ń-Methylen-bis(acryl amide) and N-tert Butyl acryl amide with poly acryloyl chloride in the presence of triethyl amine $\left(\mathrm{Et}_{3} \mathrm{~N}\right)$ as catalyst, the second step include homopolymerization of all products of the first step by using benzoyl peroxide(BPO) as initiator in $(80-90) \mathrm{C}^{\circ}$ in the presence of Nitrogen gas $\left(\mathrm{N}_{2}\right)$. In the third step the poly acrylimide which prepare in second step was convert into potassium salt by using alcoholic potassium hydroxide solution.

Fourth step include Alkylation of the prepared polymeric salts in third step by react it with different alkyl halides(benzyl chloride, allylbromide, methyl iodide) by using DMF as solvent for(10-12) hours.

Structure Confirmation of all prepared polymers were proved using FT-IR, ${ }^{1} \mathrm{H}-\mathrm{NMR}$ and $\mathrm{C}^{13}$-NMR spectroscopy for some polymers. Other physical properties including softening and melting points of the polymers were also measured.
\end{abstract}

\section{Keywords: Synthesis, Polymerization, Poly Acryl Imide, Alkyl Halide}

\section{Introduction}

Poly imides have became one of the most important and versatile classes of high performance polymer due to excellent mechanical and thermal properties [1]. Poly imides are step polymers or condensation polymers derived from both aliphatic or aromatic dianhydrides and diamines, or their derivatives (acid chlorides and amides. The poly imides contain either a hetero cyclicimide linkage or open imide linkage in the repeating unit.

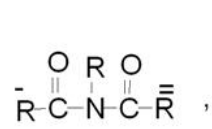

Mola [2] prepared a new polymer ester-imide starting from polymer (vinyl alcohol). The poly (vinyl alcohol) was modified to poly (carboxylic acid-ester) and then to poly

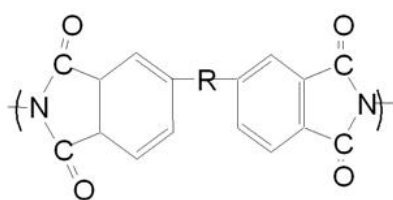

(imide-ester) by the reaction with poly acryloyl chloride :

\footnotetext{
* Department of Chemistry, College of Science, University of Baghdad, Iraq

** Department of Chemistry, College of Science for women, University of Baghdad, Iraq.
} 


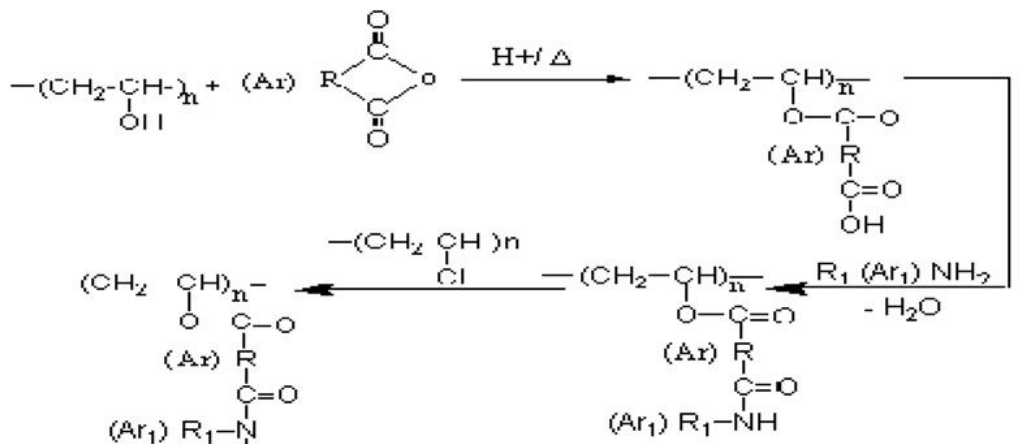

$$
\begin{aligned}
& \left(\mathrm{CH}_{2}-\mathrm{CH}-\right)_{n}
\end{aligned}
$$

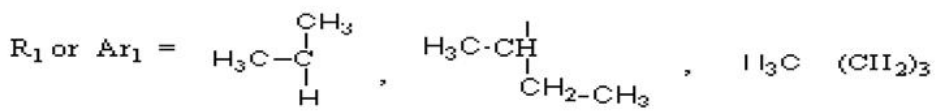

$$
\begin{aligned}
& { }_{1}^{C C_{3}}
\end{aligned}
$$

Pyradi and Altamimi [3-6] synthesized several new poly [N-(allyl)- substituted imides] curing the unsaturated resins by free radical. Nabil [7] prepared modified polymers containing pendent imide group starting from poly vinyl alcohol and methyl methacrylat. Also,
Al-Tamimi. Et.al [8] prepared Nsubstituted poly dimides by two steps. First step, include the preparation of Nsubstituted diamides by the reaction of a dipoyl chloride different amines. The second step involved the reaction of diamides with poly acryloyl chloride.

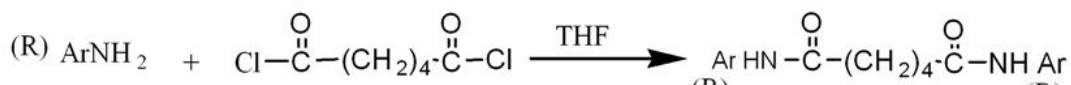
(R)<smiles>[R17]NC(=O)CCC(=O)N([Ga])C(=O)[C@H](C)CC</smiles>

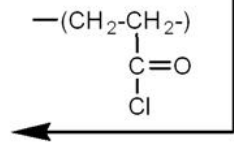

reflux, DMF (9hours)
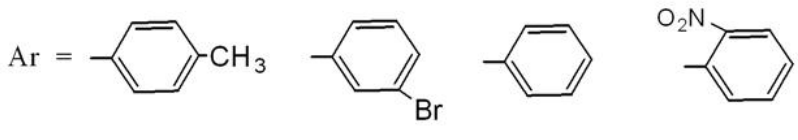

$\mathrm{R}=-\mathrm{CH}_{2}\left(\mathrm{CH}_{2}\right)_{2} \mathrm{CH}_{3}$ 
Poly imides is often used in the electronics industry for flexible cables, as an insulating film on magnet wire and for medical tubing for example, in laptop computer [9-10]. Also, electrode membrane Assemblies EMA using sulfonated polyimide membranes as polymer electrolyte and sulfonated polyimide solutions as protonic conductors was realized [11].

Poly acrylamide PAM is a generic term applying to an extensive class of organic chemical compounds [12]. Poly acryl amides (PAMS) have many different applications because of their high viscosity. PAMS are also used as an additive in drilling muds for oil extraction as well as for photographic film and battery housings. In addition, PAMS are the major components used ingel electrophoresis for proteins and nucleic acids [13]. PAM applications often allow higher water applications without run off. Center pivot and linear move system travel speeds can be reduced to permitgreater applied depths per rotation which, in turn, may reduce the amount of time poliage is wetted (less disease), have less evaporation losses and increased efficiencies. Then from PAM applications, for examples synthetic polyelectrolytes based on Acryl amide and their application as a Floceulent in the treatment of palm oil mill effluent [14-15].

\section{Materials and Methods:}

Preparation of poly [vinyl Alkyl or Aryl N-substituted Imide [16]

In around bottom flask equipped with a magnetic bar stirrer and reflux condenser was placed a mixture of poly (acryloyl chloride) (0.06 mole) and ( 0,06 mole) of acryl amide $N, \hat{N}$ methylen-bis (acryl amide) and N-tert butyl acryl amide with $(2 \mathrm{ml})$ of $\mathrm{Et}_{3} \mathrm{~N}$ (triethyl amine) in $25 \mathrm{ml}$ of suitable solvent (DMF, DMSO) and refluxed for (6-9) hrs. After cooling the exess of solvent was removed under vacuum and the solid separated was filtered and purified by dissolving in DMF or DMSO and reprecipitating from water or acetone or ethanol. This procedure applicated on compounds (1-2). All physical properties are listed in Table (1)

\section{Homo polymerization of poly [vinyl}

Alkyl or Aryl N-substituted Imide]

\section{[17]}

Literature procedures were used in the free radical homopolymerization of poly [N,N-di acryl imide], poly N, $\mathbf{N}$ - Methylen- bis (acryl amide) and poly [N-acryl-N-tert butyl acryl imide] with some modification pure monomer, poly $\{\mathrm{N}, \hat{\mathrm{N}}$-diacryl imide], poly $\mathrm{N}, \hat{\mathrm{N}}$ methlen-bis (acryl amide) and poly [Nacryl-N-tert butyl acrylimide (1-2) g were dissolved in (25-30) $\mathrm{ml}$ of freshly disstilled dry DMF or DMSO in a screw-capped polymerization bottle, an amount equal to $0.02 \%$ of the monomers weight of benzoyl peroxide was added. The bottle was flushed with nitrogen for few minutes inside a glove 10 age and firmly stoppered. The clear solution was maintained at (70-80) C in a constant temperature water bath for (3-4) hours. The solution was then poured inti about $100 \mathrm{ml}$ of methanol and a precipitate was settled. The precipitate was collected by filtration, washed with methanol several times and dried.

Preparation of poly imides salts [9]

Literature procedure was used with some modification, in a round bottom flask equipped with a magnetic bar stirrer and reflux condenser was placed a product of homo polymerization of poly [N, Ń -diacryl imide] in paragraph (2-4) (0.02 mole) and dissolved in absolute ethanol (150 
$\mathrm{ml}$ ) with $20 \mathrm{ml}$ of DMSO and heated for (6-10) hrs until the solution almost became clear. The hot solution was poured into a solution of potassium hydroxide $(0.02 \mathrm{~g})$ in $20 \mathrm{ml}$ of absolute ethanol. The mixture was cooled, the formed precipitate was filtered and washed with a solvent such as ethanol, acetone......etc. All physical properties of the products are listed in table (1).

Preparation of poly Imides Alkylates [19]

The product in (2-5) was transformed to $250 \mathrm{ml}$ round bottom flask fitted with a dropping funnel, then $(250 \mathrm{ml})$ of absolute ethanol was added, alter $(10.6 \mathrm{~g}, 0.1 \mathrm{~mol})$ of sodium carbonate was added $(14.6 \mathrm{ml}$; $0.1 \mathrm{~mol}$ ) of alkyl halide (allyl bromide, benzyl chloride, methyl iodide) was allowed to run through the dropping funnel dropwise with stirring for $1 \mathrm{hr}$, the stirring and

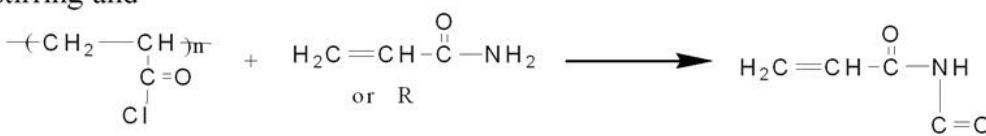

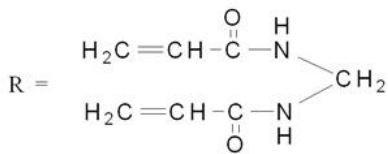

$$
\begin{aligned}
& \mathrm{H}_{2} \mathrm{C}=\mathrm{CH}-\stackrel{\mathrm{O}}{\mathrm{C}}-\mathrm{NH}-\mathrm{C}\left(\mathrm{CH}_{3}\right)_{3}
\end{aligned}
$$

refluxing continued for (11-16) hrs. Then the reaction mixture was filtered and purified by dissolving at DMF or DMSO and reprecipitating from water or ethanol, methanol, dioxane....etc

All physical properties of the products are listed in table (1).

\section{Results and Discussion} steps

3.A- First step: preparation of poly (N-acryl substituted imide[1-2] two new polymers were prepared by the reaction of poly (acryloyl chloride) with acrylamide, N, N - methylen-bis(acryl amide) and N-tert Butyl acryl amide in the presence of trimethylamine $\left(\mathrm{Et}_{3} \mathrm{~N}\right)$ as acatalyst. As is shown below: [19]
Physical properties for polymers (1-2) including softening point range of $(195-295)^{\circ} \mathrm{C}$ and percent conversion were range of (74-93.6) then spectroscopic identification of the prepared polymer such as fourier transform infrared spectra (FT-IR) [20].

FT-IR spectrum of compound (1). Shown characteristic absorption bands at $3448 \mathrm{~cm}^{-1}$,

$1700 \mathrm{~cm}^{-1}, 1410 \mathrm{~cm}^{-1},(2850-2910) \mathrm{cm}^{-}$ 1 and $1650 \mathrm{~cm}^{-1}$ due to $v(\mathrm{~N}-\mathrm{H}), v$ $(\mathrm{C}=\mathrm{O})$ imide, $\quad v \quad(\mathrm{C}-\mathrm{N}), \quad v \quad(\mathrm{C}-\mathrm{H})$ aliphatic and $v \quad(\mathrm{C}=\mathrm{C})$ vinylic respectively as shown in table (2) Fig (1). FT-IR spectrum of compound (2), showed characteristic absorption bands at $1658 \mathrm{~cm}^{-1}, 1380 \mathrm{~cm}^{-1}, 2947 \mathrm{~cm}^{-1}$ and $1527 \mathrm{~cm}^{-1}$ due to $v(\mathrm{C}=\mathrm{O})$ imide, $v(\mathrm{C}$ $\mathrm{N}), v(\mathrm{C}-\mathrm{H})$ aliphatic and $v(\mathrm{C}=\mathrm{C})$ vinylic respectively as shown in table (2)

3.B- Second step: the second step include homopolymerization of all products of the first step by using benzoyl peroxide (BPo) as imitator in $(80-90)^{\circ} \mathrm{C}$ in the presence of nitrogen gas $\left(\mathrm{N}_{2}\right)$.

As is shown below [20]: 


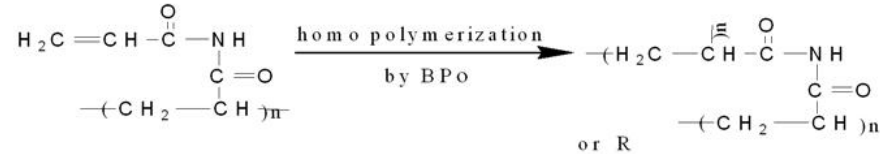

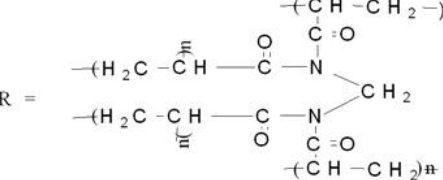

$$
\begin{aligned}
& \begin{array}{l}
\left(\mathrm{H}_{2} \mathrm{C}-\underset{\mathrm{CH}}{\mathrm{CH}}-\mathrm{O}-\mathrm{C}-\mathrm{N}-\mathrm{C}\left(\mathrm{CH}_{3}\right)_{3}\right. \\
\quad+\mathrm{C}=\mathrm{O} \\
\left.+\mathrm{CH}_{2}-\mathrm{CH}\right) \mathrm{n}
\end{array}
\end{aligned}
$$

Physical properties for polymers (3-5) including softening point range of $(220-330)^{\circ} \mathrm{C}$ and precent conversion were range of (50.7-87.5). Then spectroscopic identification of the prepared polymer such as Fourier transform Infrared spectra (FT-IR). FT-IR spectrum of compound (3), showed characteristic absorption bands at $1650 \mathrm{~cm}^{-1}, 3325 \mathrm{~cm}^{-1}, 1388 \mathrm{~cm}^{-1}$ and $(2877-2931) \mathrm{cm}^{-1}$ due to $v(\mathrm{C}=\mathrm{O})$ imide, $v(\mathrm{~N}-\mathrm{H}), v(\mathrm{C}-\mathrm{N})$ and $v(\mathrm{C}-\mathrm{H})$ aliphatic respectively as shown in table (2).

FT-IR spectrum of compound (4), showed characteristic absorption bands at $1665 \mathrm{~cm}^{-1}, 1395 \mathrm{~cm}^{-1}$ and $(2860$ 2910) $\mathrm{cm}^{-1}$ due to $v(\mathrm{C}=\mathrm{O})$ imide, $v(\mathrm{C}$ -

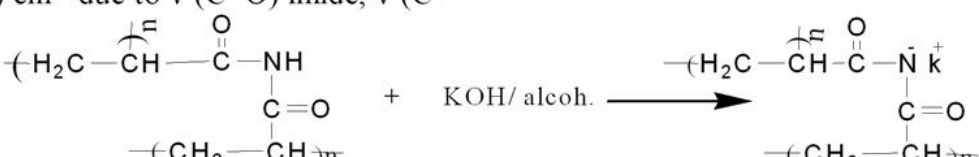

Then spectroscopic identification of the prepared polymer such as Fourier transform Infrared spectra (FT-IR).

FT-IR spectrum of compound [6] showed characteristic absorption bands at $1650 \mathrm{~cm}^{-1}, 1400 \mathrm{~cm}^{-1}$ and $(2815$ 2947) $\mathrm{cm}^{-1}$ due to $v(\mathrm{C}=\mathrm{O})$ imide, $v(\mathrm{C}$ -

N) and $v(\mathrm{C}-\mathrm{H})$ aliphatic respectively as shown in table (2).

FT-IR spectrum of compound (5), showed characteristic absorption bands at $1712 \mathrm{~cm}^{-1}, 1442 \mathrm{~cm}^{-1}$ and (27462931) $\mathrm{cm}^{-1}$ due to $v(\mathrm{C}=\mathrm{O})$ imide, $v$ (C-N) and $v \quad(\mathrm{C}-\mathrm{H})$ aliphatic respectively as shown in table (2).

3.C- third step: In the third step the poly acrylimide which prepared in second step was convert into potassium salt by using alcoholic potassium hydroxide solution with time reflux ranging between (6-8) hrs with softening point range of (285-326) ${ }^{\circ} \mathrm{C}$ and its percent conversion was (77.8). as shown below : $\mathrm{N})$ and $v(\mathrm{C}-\mathrm{H})$ aliphatic respectively as shown in table (2).

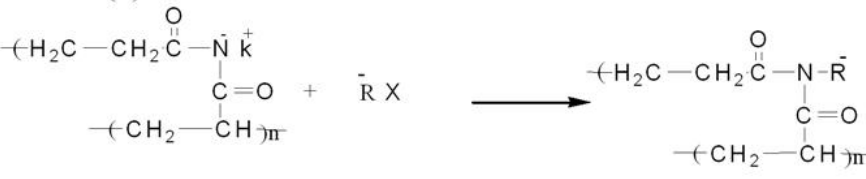

$$
\begin{aligned}
& \overline{\mathrm{R}}=-\mathrm{H}_{2} \mathrm{C}-\longrightarrow,-\mathrm{CH}_{2}-\underset{\mathrm{H}}{\mathrm{C}}=\mathrm{CH}_{2},-\mathrm{CH}_{3}
\end{aligned}
$$


New three polymers were prepared in the present work from compound (7-9). Physical properties including softening point, solubility and percent conversion of all the polymers were also measured. Physical properties for alkylated the salt of poly imides by benzyl chloride the softening point range of $(255-290)^{\circ} \mathrm{C}$ and its percent conversion was (60.8). while physical properties for alkylated the salt of polyimides by allyl bromide the softening point range of (255-296) and its percent conversion was (63.5) while physical properties for alkylated the salt of polyimide by methyl iodide the softening point range of (265-300) and its percent conversion was (62.4). Then spectroscopic identification of the prepared polymers by Fourier Transform Infrared Spectrum (FT-IR), ${ }^{1} \mathrm{H}-\mathrm{NMR}$ and ${ }^{13} \mathrm{C}-\mathrm{NMR}$. FT-IR spectrum of compound [7] showed the following characteristic features: significant band at $1620 \mathrm{~cm}^{-1}, 3047$ $\mathrm{cm}^{-1}, 1411 \mathrm{~cm}^{-1}, 1558 \mathrm{~cm}^{-1}$ and (28772900) $\mathrm{cm}^{-1}$ due to $v(\mathrm{C}=\mathrm{O}$ imide, $v(\mathrm{C}$ $\mathrm{H})$ aromatic, $\quad \mathrm{v}(\mathrm{C}-\mathrm{N}), \quad \mathrm{v} \quad(\mathrm{C}=\mathrm{C})$ aromatic and $v \quad(\mathrm{C}-\mathrm{H})$ aliphatic respectively as reported in Table (2).

FT-IR spectrum of compound [8] showed the following characteristic features: significant band at $1620 \mathrm{~cm}^{-1}$,
$1404 \mathrm{~cm}^{-1}, 2940 \mathrm{~cm}^{-1}$ and $1567 \mathrm{~cm}^{-1}$ are attributed to stretching vibration of $v(\mathrm{C}=\mathrm{O})$ imide, $v(\mathrm{C}-\mathrm{N}), v(\mathrm{C}-\mathrm{H})$ aliphatic and $v \quad(\mathrm{C}=\mathrm{C})$ vinylic respectively as reperted in table (2)

FT-IR spectrum of compound [9] showed the following characteristic features: $1650 \mathrm{~cm}^{-1}, 1419 \mathrm{~cm}^{-1},(2893-$ 2954) $\mathrm{cm}^{-1}$ due to $v(\mathrm{C}=\mathrm{O})$ imide, $v$ $(\mathrm{C}-\mathrm{N})$ and $v \quad(\mathrm{C}-\mathrm{H})$ aliphatic respectively as shown in table (2).

${ }^{1} \mathrm{H}-\mathrm{NMR}$ spectra of some of the prepared polymers were obtained DMSO-d6 as solvents with TMS as internal standard.

All ${ }^{1} \mathrm{H}-\mathrm{NMR}$ spectra of the prepared polymers revealed the monomer group of $\left.-\mathrm{CH}_{2}-\mathrm{CH}_{2}\right) \mathrm{n}$

$\delta(1.038-2.890)\left(\mathrm{t}, 2 \mathrm{H},-\left(\mathrm{CH}_{2}-\mathrm{CH}_{2}\right) \mathrm{n}\right)$, $\delta(1.125-3.102)\left(\mathrm{m}, 1 \mathrm{H},-\left(\mathrm{CH}_{2}-\mathrm{CH}_{2}\right) \mathrm{n}\right)$ Then the ${ }^{13} \mathrm{C}$-NMR spectrum obtained from a ${ }^{13} \mathrm{C}$-NMR spectrometer operating in the normal mode consists of series of sharp signals. Each signal represents a different ${ }^{13} \mathrm{C}-\mathrm{NMR}^{(22)}$. In addition, the calibration signals TMS as an internal standard. All ${ }^{13} \mathrm{C}$-NMR spectra of some of the prepared polymers showed two types signals at (24.47-35.22), (162.77-176.22) which were due to $\left(\mathrm{CH}, \mathrm{CH}_{2}, \mathrm{CH}_{3}\right), \mathrm{C}=\mathrm{O}$ respectively). 
Table (1): Physical properties of the prepared polymers

\begin{tabular}{|c|c|c|c|c|c|}
\hline $\begin{array}{l}\text { Comp. } \\
\text { No. }\end{array}$ & Structure & $\%$ Conversion & $\begin{array}{c}\text { Softing point } \\
\left({ }^{\circ} \mathrm{C}\right)\end{array}$ & Colour & $\begin{array}{l}\text { Solvent used } \\
\text { in reaction }\end{array}$ \\
\hline 1 & $\begin{array}{r}\mathrm{H}_{2} \mathrm{C}=\mathrm{CH}-\mathrm{C}^{\prime}-\mathrm{O}-\mathrm{N}-\mathrm{H} \\
\mathrm{C}=\mathrm{O} \\
\quad\left(\mathrm{CH}_{2}-\mathrm{C} H\right)_{\mathrm{n}}\end{array}$ & 93.6 & $195-230$ & Milky & THF \\
\hline 2 & 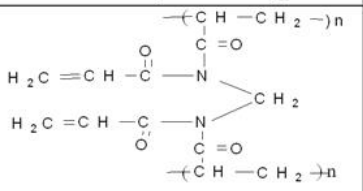 & 74 & $260-295$ & white & $\begin{array}{l}\text { DMF } \\
\text { DMSO }\end{array}$ \\
\hline 3 & 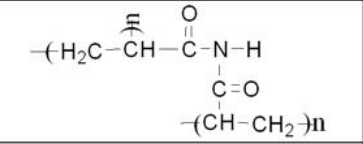 & 65.5 & $225-286$ & $\begin{array}{l}\text { Yellowis } \\
\mathrm{h} \text { brown }\end{array}$ & DMF \\
\hline 4 & 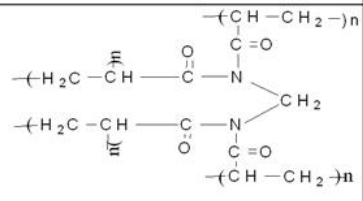 & 87.5 & $270-330$ & white & $\begin{array}{l}\text { DMF } \\
\text { DMSO }\end{array}$ \\
\hline 5 & 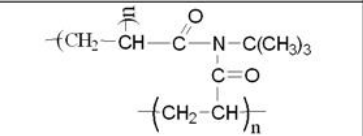 & 50.7 & $220-290$ & $\begin{array}{l}\text { Yellowis } \\
\mathrm{h} \text { brown }\end{array}$ & DMF \\
\hline 6 & 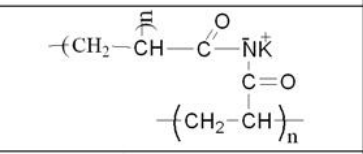 & 77.8 & $285-326$ & $\begin{array}{l}\text { Very } \\
\text { pale } \\
\text { brown }\end{array}$ & $\begin{array}{l}\text { DMF } \\
\text { DMSO }\end{array}$ \\
\hline 7 & 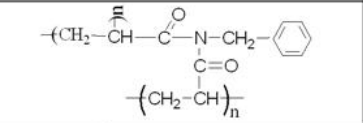 & 60.8 & $255-290$ & yellow & $\begin{array}{l}\text { DMF } \\
\text { DMSO }\end{array}$ \\
\hline 8 & 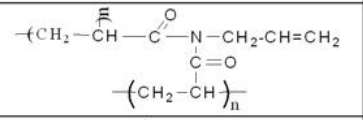 & 63.5 & $255-296$ & $\begin{array}{l}\text { Yellowis } \\
\mathrm{h} \text { brown }\end{array}$ & $\begin{array}{l}\text { DMF } \\
\text { DMSO }\end{array}$ \\
\hline 9 & 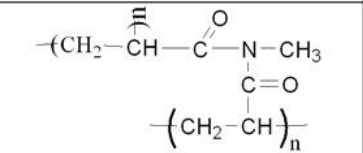 & 62.4 & $265-300$ & $\begin{array}{l}\text { Pale } \\
\text { yellow }\end{array}$ & DMSO \\
\hline
\end{tabular}


Table (2): FT-IR spectra of prepared polymer

\begin{tabular}{|c|c|c|c|c|c|c|c|c|}
\hline $\begin{array}{l}\text { Comp } \\
\text { No. }\end{array}$ & Structure & $v(\mathrm{~N}-\mathrm{H})$ & $\begin{array}{c}v(\mathrm{C}=\mathrm{O}) \\
\text { imide }\end{array}$ & $v(\mathrm{C}-\mathrm{N})$ & $\begin{array}{c}v(\mathrm{C}=\mathrm{C}) \\
\text { aromatic }\end{array}$ & $\begin{array}{l}v(\mathrm{C}-\mathrm{H}) \\
\text { aliphatic }\end{array}$ & $\begin{array}{l}v(\mathrm{C}-\mathrm{H}) \\
\text { aromatic }\end{array}$ & $\begin{array}{l}\text { Other } \\
\text { band }\end{array}$ \\
\hline 1 & $\begin{array}{r}\mathrm{H}_{2} \mathrm{C}=\mathrm{CH}-\mathrm{C}^{\circ}-\mathrm{N}-\mathrm{N} \\
\mathrm{C}=\mathrm{O} \\
\left(\mathrm{CH}_{2}-\mathrm{CH}\right)_{\mathrm{n}}\end{array}$ & 3448 & 1700 & 1410 & -..-- & $\begin{array}{l}2850 \\
2910\end{array}$ & -.-.- & $\begin{array}{c}(\mathrm{C}=\mathrm{C}) \\
\text { Vinylic } \\
1650\end{array}$ \\
\hline 2 & 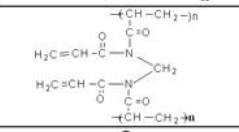 & -..-...- & 1658 & 1380 & -...... & 2947 & -..... & $\begin{array}{c}(\mathrm{C}=\mathrm{C}) \\
\text { Vinylic } \\
1527\end{array}$ \\
\hline 3 & $\begin{array}{c}\mathrm{O} \\
+\mathrm{H}_{2} \mathrm{C}-\mathrm{O}-\mathrm{H}-\mathrm{C}-\mathrm{N}-\mathrm{H} \\
\mathrm{C}=\mathrm{O} \\
+\mathrm{CH}-\mathrm{CH}_{2} \rightarrow \mathrm{n}\end{array}$ & 3325 & 1650 & 1388 & -...- & $\begin{array}{l}2877 \\
2931\end{array}$ & -..... & -..- \\
\hline 4 & 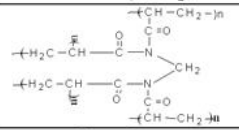 & -...-. & 1665 & 1395 & -...-. & $\begin{array}{l}2860 \\
2910\end{array}$ & -........ & -...-. \\
\hline 5 & 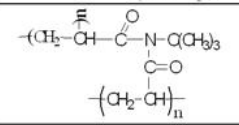 & -..- & $\begin{array}{l}1712 \\
1650\end{array}$ & 1442 & -..--..- & $\begin{array}{l}2746 \\
2931\end{array}$ & -..--.. & $\cdots$ \\
\hline 6 & $\begin{array}{r}\stackrel{\vec{E}}{\mathrm{CH}_{2}-\mathrm{CH}}-\mathrm{C}^{\circ}-\mathrm{NN}^{+} \\
\mathrm{C}=0 \\
\left(\mathrm{CH}_{2}-\mathrm{CH}\right)_{n}\end{array}$ & -..--. & 1650 & 1400 & -.-- & $\begin{array}{l}2815 \\
2947\end{array}$ & -...-.. & -..-- \\
\hline 7 & $\begin{array}{c}+\mathrm{fCH}_{2}-\mathrm{CH}-\mathrm{C}-\mathrm{N}-\mathrm{CH}_{2}-\langle\mathrm{CH} \\
\mathrm{C}=\mathrm{O} \\
\left.\mathrm{f} \mathrm{CH}_{2}-\mathrm{CH}\right)_{\mathrm{n}}\end{array}$ & -..-..- & 1620 & 1411 & 1558 & $\begin{array}{l}2877 \\
2900\end{array}$ & 3047 & -...-. \\
\hline 8 & 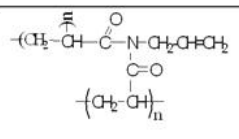 & & 1620 & 1404 & & 2940 & -..-.. & $\begin{array}{l}(\mathrm{C}=\mathrm{C}) \\
\text { Vinylic } \\
1557\end{array}$ \\
\hline 9 & $\begin{array}{r}-\mathrm{O} \\
+\mathrm{CH}_{2}-\mathrm{CH}-\mathrm{C}^{\prime}-\mathrm{N}-\mathrm{CH}_{3} \\
\mathrm{C}=\mathrm{O} \\
\left(\mathrm{CH}_{2}-\mathrm{CH}\right)_{n}\end{array}$ & & 650 & 1419 & & $\begin{array}{l}2893 \\
2954\end{array}$ & .......... & \\
\hline
\end{tabular}

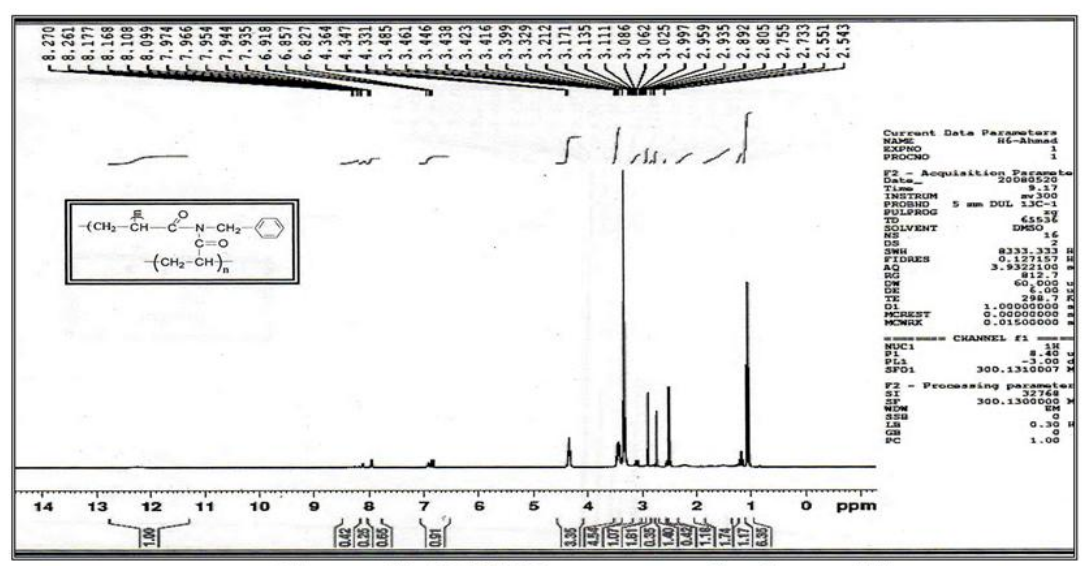

Figure (1): H-NMR spectrum of polymer [7] 


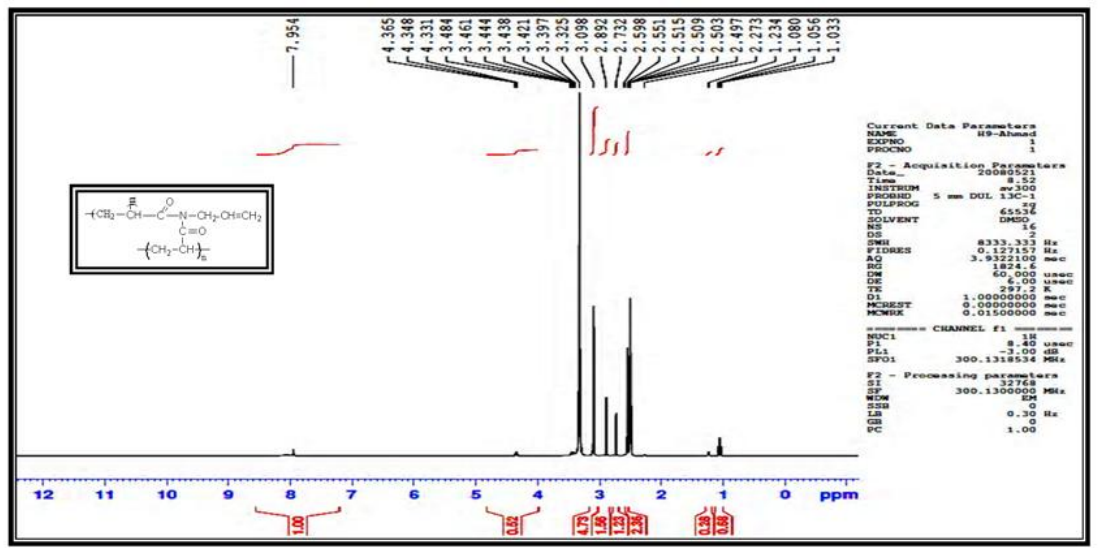

Figure (2): ${ }^{1} \mathrm{H}-\mathrm{NMR}$ spectrum of polymer [8]

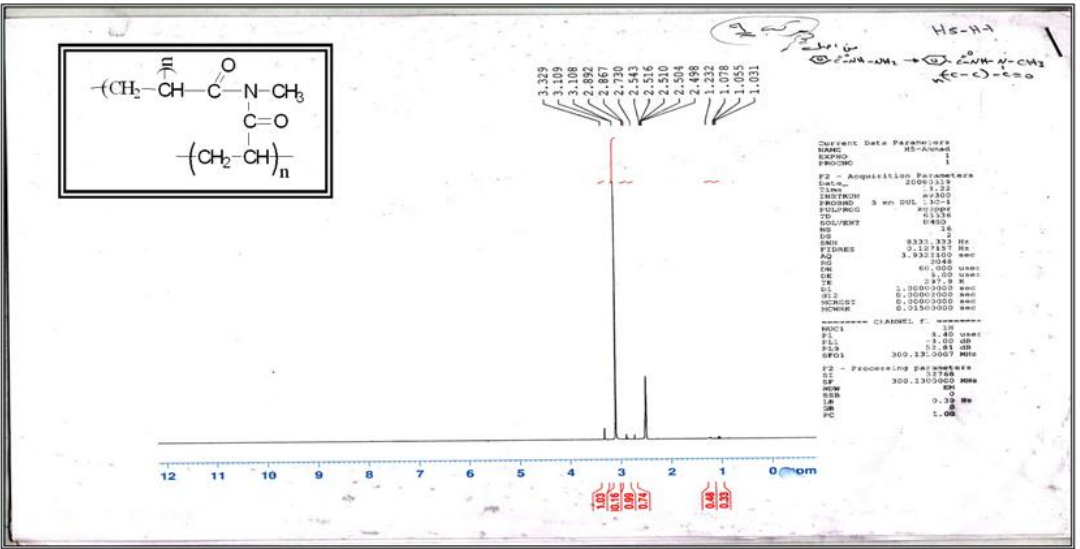

Figure (3): ${ }^{1} \mathrm{H}-\mathrm{NMR}$ spectrum of polymer [9]

\section{References:}

1- A.D. Bowens, 1999. Ph.D. Thesis, Faculty of the Virginia polytechnic Institute State University,

2- H. Mola, 2008. M.Sc. Thesis, College of Science For Women, University of Baghdad.

3- T. M. Pyriadi and A. Shehab, 1995. Iraqi J. Sci., vol. 36 (1), p 109 .

4- A.M. Alazzawai, 1998 Ph.D. Thesis, College of Science, University of Baghdad.
5- T.M. Pyriadi and E.O. AlTamimi, 1999 Iraqi-Sci., vol. 40A (4), pl4.

6- T.M.Pyriadi and E.O. Al-Tamimi, 2001. The first Conf. of Chemistry, College of Education.

7- N. J. Al-Asli, 2000. Ph.D. Thesis, College of Sceince university of Baghdad.

8- E. O. Al- Tamimi; L.S. Ahmed, 2009. Journal of Um-salama for Science, Vol 5(1), p.116,

9- M.S.H. Al-Nuaimi, 2006 Ph.D, Thesis, College of Education, University Of Tikrit. 
10-N.S. Shim; Y.J. Kwon, 2009 Bioconjucate Chem., Vol.20, p. 488.

11-S. Bsse: P.Capron: O. Diat: R.Mercier, 2002. Journal of new materials for electrochemical systems, Vol. 5, P.109.

12- A. Ariffin: A.R. Nik Norulaini and A.K. Mohd Omer, 2004. J. of Applied Science. Vol 4(3), p.393.

13-M.Solener; S. Tunali and A. Safa Ozcan,2008. Desalinaion, Vol (223), p.308.

14-E. Uguzdogan, T.Camli and A. Tuncel, Euro-Polym. 2005. J., Vol 41(9), p.2142.

15-M. N. Al-Baiati, 2008. Ph.D Thesis, College of Science for women, University of Baghdad.

16-S. M. Al-Majidi, 2003. Ph.D. Thesis. College of science, Dept of Chem., University of Baghdad.
17-E.O. Al-Tamimi, 1998. Ph.D Thesis, College of Science, Dept of Chem., University of Baghdad.

18-V. Ondrus, L. Fisera, 1997. Molecules, Vol. 2, p.49,

19-B.S. Holla, B. Kallurage, K.R. Sridhar, I.Drake, K.K. Bhan-dray and M.J.Levince, 1994, J. Med. Chem., Vol 29(4), p.301,

20-F.A. Carey, R. J. Sundber, 2007."Advanced Organic Chemistry Part A: Strcture snd Mechanisms", $5^{\text {th }}$ ed. New York,.

21-R.M. Solverstein, F.X. Webster, D. J. Kiemle, 2005 "Spectrometric identification of Organic Compounds" $7^{\text {th }}$ ed., John Wiley and sons, Inc.,.

22-P.Crews; J. Rodriguez; M.Jaspars, 1998 "Organic Structure analysis, Oxford University Press, New York,

\section{تحضير وبلمرة بولي اكريل امايد ومعاملة احد نواتج مشتقاتة مع هاليد الاكليل}

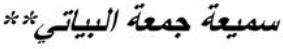

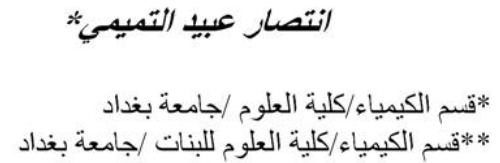

الخلاصة

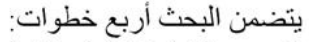

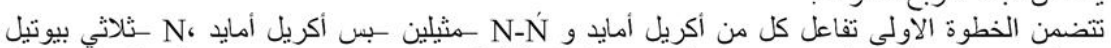

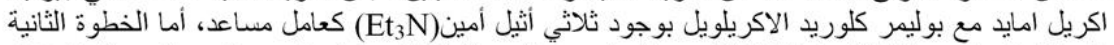

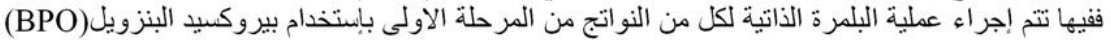

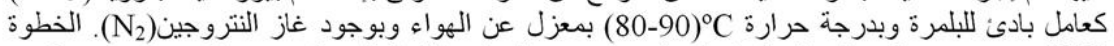

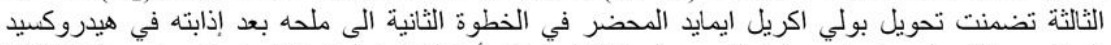

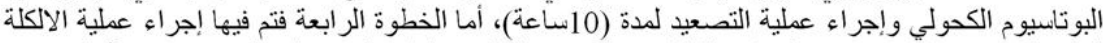

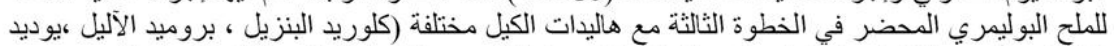

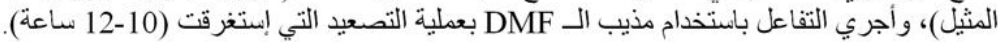

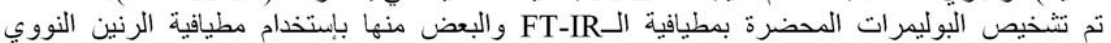

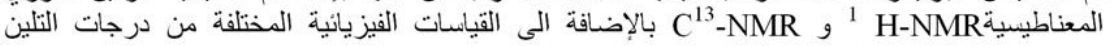
ودرجات الإنصهار وكذلك قياس PH المحلول للبولي ايمايد المحضر . للئ 